\title{
Article \\ Safety or Travel: Which Is More Important? The Impact of Disaster Events on Tourism
}

\author{
Haiyan Ma ${ }^{1}$, Yung-ho Chiu ${ }^{2, *}$, Xiaocong Tian ${ }^{3}{ }^{-}$, Juanjuan Zhang ${ }^{3,4}$ and Quan Guo ${ }^{5}$ \\ 1 School of Management, China University of Mining and Technology, Xuzhou 221116, China; \\ mhy7605@126.com \\ 2 Department of Economics, Soochow University, Taipei 10048, Taiwan \\ 3 College of Business, Shanghai University of Finance and Economics, Shanghai 200433, China; \\ tian.xiaocong@sufe.edu.cn (X.T.); zhjuanjuansufe@126.com (J.Z.) \\ 4 College of Tourism, Henan University of Animal Husbandry and Economy, Zhengzhou 450046, China \\ 5 School of Business, Global Institute of Software Technology, Suzhou 215000, China; gqteacher@cumt.edu.cn \\ * Correspondence: echiu@scu.edu.tw
}

Received: 17 March 2020; Accepted: 8 April 2020; Published: 10 April 2020

check for updates

\begin{abstract}
Tourism is making an increasingly considerable contribution to the sustainable development of world economy, but its development is susceptible to a series of disaster events. The impact of disaster events on tourists' travel decisions is receiving ever-growing attention. In this study, disasters are classified into two categories: namely, natural disasters and man-made disasters. Among these disasters, earthquakes and terrorist attacks-as the most representative two types-are taken as research examples. By virtue of a difference-in-difference research method and online review data from TripAdvisor, multiple incidents that have occurred in different countries are systematically and comparatively analyzed for verifying the effects of catastrophic events with varying natures, frequencies, and intensities on tourism. The main findings are as follows: (1) both natural disasters and man-made disasters have a negative effect on the number of tourists and the tourist experience; (2) higher frequency and intensity of terrorist attacks may not correspond to tourism, and terrorist attacks exert a more influential impact on the safety image of tourist destinations; (3) compared with the scale and intensity of earthquakes, the frequency of earthquakes has a greater effect on tourism; (4) compared with terrorist attacks, earthquakes have a greater effect on the number of tourists.
\end{abstract}

Keywords: terrorist attacks; natural disasters; number of tourists; tourist experience

\section{Introduction}

Tourism, which is closely related to the sustainable development of economy, is an important green approach to targeted poverty alleviation for China. Wu et al. proposed that the path of realizing targeted poverty alleviation by rural tourism can be optimized through improving four mechanisms: the mechanism of participation and benefit of the poor, the mechanism of linked operation of tourism-oriented poverty alleviation, the mechanism of subject coordination of tourism-oriented poverty alleviation, and the mechanism of target assessment of tourism-oriented poverty alleviation [1]. Meanwhile, tourism carries the important mission for people to achieve a better life. As the first of "five happiness industries", tourism will play a leading role in meeting people's needs for a better life [2]. As the subject of tourism activities, tourists conduct tourism activities that are highly related to their happiness essentially for the purpose of pursuing physical and mental pleasure [3]. As Aristotle said, happiness is the sole goal and purpose of human existence. Tourism, an important way for human beings to gain happiness, has been integrated into more people's lives and has become a way of life.

Scholars in different fields focus on different aspects of tourism in their research. Economists are concerned about the contribution of tourism to the national economy and destination economy, as 
well as the relationship between supply and demand. Sociologists and cultural anthropologists pay attention to the travel behavior of individuals and groups. The competitiveness of a tourist destination is "its ability to attract tourists and give them a satisfactory visiting experience, to realize the value demands of destination stakeholders, and to maintain the sustainable utilization of local relevant resources" [4]. A balance needs to be found between improving local residents' quality of life and satisfying tourists' travel experience. If handled properly, tourism can be a huge driving force for expanding social goals [5]. Therefore, the microscopic research on tourists and the decision-making of tourists is as important as the macroscopic research on tourism economy. It is essential to explore favorable factors attracting tourists and unfavorable factors hindering tourists. Through the balance of the two categories of factors, scientific suggestions can be put forward to promote the healthy and sustainable development of the local tourism economy. In this study, unfavorable factors that affect the development of tourism are focused on. Specifically, factors that may prevent tourists from heading to tourist destinations are sorted, and various dangerous factors that notably impact our daily life are analyzed. Furthermore, the impact of these factors on the tourism industry, the degree of the impact, and the causes and mechanisms of the impact are investigated. Finally, suggestions are put forward on this basis.

Scholars have discussed factors influencing tourist destination selection from different perspectives. Kang and Hsu investigated the dyadic consensus in the process of vacation destination selection in a family. They believed that family is the most important decision-making and consumption unit, and the spouse's decision-making thoughts will affect the choices of tourist destination, transportation, accommodation, entertainment activities, restaurants, etc. [6]. Nanda et al. studied the marketing strategies of tourism and hotel industry, revealing that core family members play different roles in the purchasing decisions during vacation planning [7]. In the research on married couples' decision-making about household natural hazard preparedness, Hung found that the couples who make decisions together account for the largest proportion [8]. Kaplan et al. assessed the physical, psychological, social, financial, performance, and overall perceived risks associated with the purchase of 12 products and concluded that similar products show similar risk component hierarchies [9].

In summary, it is believed that tourists' decisions on tourist destination selection are based on tourism motivation and are influenced by the judgment and balance process of a series of cognitive functions and self-defense functions. In this process, safety is an important factor.

The study indicates that tourism is susceptible to external environmental factors, such as natural and man-made disasters [10]. Over the past decade, tourism has suffered a variety of disasters and crises, including terrorist attacks, political crises, economic recession, and natural disasters. These disasters and crises have brought huge challenges to the survival and recovery of the tourism industry [11]. Disasters have become one of the key factors that seriously restrict the sustainable development of world tourism [12].

In terms of natural disasters, the Taiwan earthquake in 1999 caused a 15\% decrease in the number of international tourists from September to December [13]. On 26 December, 2004, the Indian Ocean tsunami killed more than 225,000 people in the region. This tsunami disaster, as the one causing the largest casualty (including tourists and tourism workers) in the world over the past 200 years [14], led to a significant decline in tourist arrivals to the Maldives (-69.7\%) [15]. The European airline industry may have lost up to E2.5 billion ( $£ 2.15$ billion) under the influence of the volcanic ash cloud generated by the Iceland volcanic eruption in 2010 [16].

In regard to man-made disasters, the $9 \cdot 11$ terrorist attacks that occurred in the United States in 2001 impaired the trust of tourists, and required a long-term recovery period, with arrivals regaining their losses in around January 2005-a period of almost four years. [17]. The Bali bombing in Indonesia that targeted tourists in 2005 was responsible for about 400 deaths and caused the local tourism industry to be stalled for a long time [18]. The financial crisis in 2008 reduced the number of international tourists in 2009 by $4 \%$ [16]. Tourism is an industry whose supply and demand are sensitive to disaster events [19]. The occurrence of disaster events not only physically damages the tangible assets (facilities 
and infrastructure) of tourist destinations within a relatively short time frame, but also makes it difficult to restore the reputation and image of the destination in the long-term. At the same time, given the sensitivity of the tourism demand for safety, tourists will undoubtedly cancel their travel plans once they are aware that the trip to a destination may threaten their safety. Consequently, the sales of products at tourist destinations will decline [20].

Over the last five decades, tourism has been suffering from such crises and disasters, and few tourist destinations can be fully exempt [21]. These facts cast a heavy shadow on the development of the global tourism industry. As a result, many tourists begin to doubt the safety and security of the tourist attractions and destinations they plan to visit [22]. The main contributions of this study can be summarized as follows: (1) disasters are classified into natural disasters and man-made disasters. Among the two categories, earthquakes and terrorist attacks-as two of the most representative types-are taken as research objects to study and evaluate the impact of disasters on the number of tourists and the tourist experience by adopting the difference-in-difference (DID) research method. (2) Multiple disaster events that have occurred in different countries are systematically and comparatively analyzed for verifying the effects of catastrophic events with varying natures, frequencies, and intensities on tourism. (3) By virtue of the DID research method and online review data from TripAdvisor, this study provides novel and comprehensive empirical evidence for the specific impact of disaster events on the tourism industry and fills a gap in the relevant tourism literature review.

\section{Literature Review and Hypotheses}

\subsection{Literature Review}

\subsubsection{The Impact of Disasters on Tourism}

According to Murphy and Bayley, the word disaster refers to sudden, random, or great misfortune [23]. Carter proposed that a disaster is a natural or man-made, sudden or progressive event, and its impact on the community is so severe that the affected communities have to take special measures [24]. Briere and Elliott believed that disasters are events that cause fatal damage or injury, such as a volcanic eruption, fire, earthquake, typhoon, tsunami, flood, or drought [25]. Perrow argues that disasters can also be incurred by intentional and unintentional human behavior, such as terrorism, technical faults, and industrial failures [26]. Susanne and Kennet defined disasters as "a serious disruption of the functioning of a community or a society causing widespread human, material, economic or environmental losses which exceed the ability of the affected community or society to cope using its own resources" [27]. Many studies have demonstrated that disasters occurring in tourist destinations severely affect the local tourism industry. For example, Matthew (2019) explored the impact of the California wildfires occurring between October, 2017 and January, 2018 on the tourism industry in the United States. The results show that the wildfires immediately reduced $71 \%$ of North Coast wineries in tasting room traffic compared to the same period last year, and tasting room sales dropped by $62 \%$ compared to the previous year [28]. Shaen (2019) assessed the influence of terrorist attacks on European tourism through short-term hindsight responses from the airline industry and passengers. The results showed that after the terrorist attacks, even the sharply dropping air ticket prices could hardly prevent the significant decline in passenger demands [29].

Combining the above viewpoints and our research purpose, in this study, a disaster is accordingly defined as a natural or man-made, sudden or progressive event that causes fatal damage or injury. The dual attributes (natural and social attributes) of a disaster determine its multidimensional, comprehensive, and far-reaching impact [30].

According to the widely accepted classic view of Gunn [31], attractions are indispensable to tourism [31]. The different cultures and environments are like a magnet for tourists who want to escape from their normal lives. However, in addition to the four " $\mathrm{s}$ " core attraction elements-i.e., sun, sand, sea, and sex-the fifth "s" element, security, may be more important. Nowadays, the growing sense of insecurity caused by terrorism and natural disasters means that the attractiveness 
of a tourist destination is almost determined by its assurance of the tourist's safety and security [32]. Travel behavior, as a kind of consumer behavior, is accompanied by risk. When seeking stimulation poses a degree of risk that may endanger personal safety and implies unpleasant consequences, the destinations that are considered risky or unsafe may be rejected [33]. In short, attractions are important for tourism development, but it is not enough to be a necessary condition for the success of a tourist destination because: "no safety, no tourism" [22].

Fareed et al. suggested that sudden insecurity has a significant impact on tourist demand, as it is associated with destruction, death, and tragedy [34]. Mendiratta argued that the increasing frequency and severity of natural and man-made disasters have posed challenges to people's physical and psychological safety [35] because tourists, like everyone else, value tranquility and peace while enjoying the pleasures and activities offered by the destinations [19]. Poku et al. pointed out that some tourists believe that disasters may occur anytime, anywhere, in any form without any warning, which causes them to fear seeking leisure [22].

Moreover, if a tourist feels unsafe or threatened at a destination, he or she may have a negative impression of the destination and no longer repeatedly visit the destination or recommend it to others. Meanwhile, prospective tourists may decide not to visit the destination because of its negative reputation [13].

Tourism is special in that its activities may be shrouded by risks that may be harmful to safety and health [32]. These disasters can be considered as major obstacles to tourist destinations, as tourists often show an obvious preference for a peaceful social environment $[36,37]$.

\subsubsection{Natural Disasters and Earthquakes}

As a natural power that causes catastrophic events, natural disasters include volcanic eruptions, tsunamis, floods, landslides, hurricanes, cyclones, typhoons, tornadoes, earthquakes, avalanches, heat waves, droughts, winter storms, and wildfires [38]. Natural disasters are inevitable because they are beyond human control [39]. They often result in life loss and economic, physical, and social damage $[40,41]$.

Tourist destinations are susceptible to various natural disasters [23] that will severely damage the tourism system. Because of the particular and widespread characteristics of the tourism industry, tourists - for instance, free independent tourists and tourists involved in outdoor activities or those seeking accommodation on or near water-are particularly vulnerable to threats from many natural disasters [27]. Natural disasters also provoke tourists' perception of psychological risk. For example, earthquakes will enhance people's fear of "nowhere to escape". These psychological impacts on tourists will lead to a decline in tourism demand [42].

Among various natural disasters, earthquakes are one of the most severe and unpreventable catastrophic events [27]. They can lead to incalculable environmental damage, building damage, loss of life, population displacement, and epidemics that threaten human health [43]. Taking the 9.21 earthquake in Taiwan in 1999 as an example, 2400 people died, 8000 people were injured and 100,000 people became homeless in this earthquake (TBT, 2000). Although a large amount of funds were invested in infrastructure restoration afterwards, Taiwan's international tourism did not fully recover until 2001 [44].

In the past decade, some earthquake disasters have caused huge losses to tourist destinations by greatly reducing the number of tourists who visit relevant tourist sites and seriously damaging the tourist attractions and facilities. Resultantly, communities can hardly maintain their livelihoods [12]. The most prominent examples include the earthquake in Japan in 2011 and the continual earthquakes in New Zealand in the period of 2010-2016. On 11 March, 2011, an earthquake measuring 9.0 on the Richter scale occurred in Japan, which triggered a tsunami and a subsequent nuclear accident, resulting in huge casualties and property damage. It is regarded as the worst natural disaster in Japanese history $[45,46]$. Due to the unpredictable impact of the nuclear leak caused by the earthquake, potential tourists believe that they have to take a huge risk of suffering from nuclear radiation if they travel to 
Japan. Consequently, the number of tourists dropped notably [15]. In New Zealand, tourism is also regarded as an important pillar industry. However, a total of about 20,000 earthquakes (excluding small earthquakes with magnitudes below 3.5 and a focal depth over $100 \mathrm{~km}$; if included, this number would reach 250,000) have been detected since 2008. The consecutive earthquakes considerably affect New Zealand's tourism infrastructure and the number of tourists [47].

\subsubsection{Man-Made Disasters and Terrorist Attacks}

Tourism has become one of the industries that is most prone to man-made disasters $[19,48,49]$. Generally speaking, man-made disasters can be divided into three categories: safety-related disasters, financial and economic crises, and political crises.

Corbet et al. believed that terrorism engenders fear through violence or threat to the safety of tourist destinations, resulting in the disruption of tourist flow, infrastructure, and overall operations [29] — that is, terrorism aims to create a circumstance of prevalent fear and insecurity, and, thus, becomes a significant obstacle to the international tourism industry [50].

In terms of its repercussion, terrorism often prevents tourists from visiting affected destinations [50]. According to Fletcher and Morakabati (2008), the terrorist attacks that occurred in Mombasa, Kenya, in 2003 led to a decrease in the number of local leisure tourists of $7 \%$ and a reduction in the number of overnight tourists of 31\%, from 2.766 million to 1.89 million [32]. Lanouar and Goaied (2019) investigated the impacts of terrorist attacks and political violence on the number of tourists arriving and staying overnight in Tunisia. The results showed that, compared with political violence (the Jasmine Revolution, 8 months), terrorist attacks exert more serious and more lasting ( 1 year and 2 months) impacts on tourism activities [51]. In viewing the serious impact of terrorist attacks on tourism, Lepp and Gibson (2003) pointed out that if terrorists want to destroy a country's economy, they will attack the countries that regard tourism as one of their major exports [52].

Since the beginning of this century, many developed democracies have experienced multiple terrorist incidents, including the 9.11 terrorist attacks in New York in 2001, the Madrid bombings in 2004, the London terrorist attacks in 2005, and the terrorist attacks in Brussels, Paris, and Berlin in 2016. All these incidents have markedly perturbed tourism [51].

\subsection{Hypothesis}

Based on the above studies, a natural or man-made disaster in the tourist destination often causes the fear and insecurity of tourists. For the sake of their own personal safety, they will avoid places with higher risks and choose a tourist destination with a peaceful social environment, because safety may be the most important factor in comparison with the happiness and joy brought by traveling. Thus, unexpected disasters will seriously affect the development of the tourism industry, impair the confidence of travelers, and may even cause the local tourism industry to be stalled for a long time.

Despite the increasing global interests in the impact of natural and man-made disasters on tourism, most researchers only focused on the effect of a single disaster event on a certain country's tourism industry during a period of time. For example, Huan et al. (2004) probed into the impact of the 9.21 earthquake in Taiwan on local tourism in 1999 [44]. Jorge and Carmelo (2008) studied the impact of the 9.11 terrorist attacks on the number of tourists traveling to the Mediterranean and Canary Islands [19]. Bowen et al. (2014) explored the impact of terrorism on cruise tourism [53]. James et al. (2018) analyzed the continuous change in the number of inbound tourists to the United States after the 9.11 terrorist attacks [54]. Dlawar et al. (2019) researched the impact of terrorist attacks on the performance and stock volatility of tourism enterprises in major tourism countries [55]. Nevertheless, few systematic studies or controlled studies have been conducted on the influence of a particular type of disaster. Therefore, on the basis of previous studies, earthquakes and terrorist attacks-as the two most representative and influential types of catastrophic events among natural and man-made disasters-are taken as research objects in this study. Both study objects are of different scales and frequencies in multiple countries. 
The two types of disasters are studied systematically and comparatively to thoroughly verify the effect of catastrophic events on tourism. The following hypotheses are proposed:

Hypothesis 1a. Natural disasters have a negative influence on the number of tourists.

Hypothesis $\mathbf{1 b}$. Natural disasters have a negative influence on the tourist experience.

Hypothesis 1c. The negative influence of natural disasters on the number of tourists is stronger when the frequency of natural disasters is higher.

Hypothesis 1d. The negative influence of natural disasters on the tourist experience is stronger when the frequency of natural disasters is higher.

Hypothesis 2a. Terrorist attacks have a negative influence on the number of tourists.

Hypothesis $\mathbf{2 b}$. Terrorist attacks have a negative influence on the tourist experience.

Hypothesis 2c. The negative influence of terrorist attacks on the number of tourists is stronger when the frequency of terrorist attacks is higher.

Hypothesis $\mathbf{2 d}$. The negative influence of terrorist attacks on the tourist experience is stronger when the frequency of terrorist attacks is higher.

\section{Method and Data}

\subsection{Method}

In order to test the above hypotheses, earthquakes and terrorist attacks in different countries were used as natural experiments, with adjacent or similar countries where no disaster happened chosen as a control group for comparative research.

Specifically, the DID analysis was adopted to test the hypotheses. DID, which is a common practice for natural experiments, can eliminate the influence of unobservable external interference factors and help solve endogenous problems. The statistical model used to test the hypotheses about the number of tourists was as follows:

$$
\begin{aligned}
\text { Flow }_{i t}=\beta_{0}+\beta_{1} \text { PostEvent }_{t} \times & \text { TreatedGroup }_{i}+\beta_{2} \text { PostEvent }_{t}+\beta_{3} \text { TreatedGroup }_{i}+\beta_{4} X_{i} \\
& + \text { CountryFE }+ \text { YearFE }+ \text { MonthFE }+\varepsilon_{i t}
\end{aligned}
$$

where $i$ represents different attractions and $t$ represents a certain month; PostEvent $t_{t}$ equals 1 after the event and 0 before the event; TreatedGroup $i$ is assigned the value of 1 if the attraction belongs to the experimental group, and 0 otherwise; $X_{i}$ shows whether the attraction pertains to world heritages; CountryFE, YearFE, and MonthFE represent the fixed effects of country, year, and month, respectively.

The statistical model used to test the hypotheses on tourist experience was as follows:

$$
\begin{aligned}
& \text { Experience }_{i t}=\beta_{0}+\beta_{1} \text { PostEvent }_{t} \times \text { TreatedGroup }_{i}+\beta_{2} \text { PostEvent }_{t}+\beta_{3} \text { TreatedGroup }_{i} \\
& +\beta_{4} X_{i}+\text { CountryFE }+ \text { YearFE }+ \text { MonthFE }+\varepsilon_{i t}
\end{aligned}
$$

where $i$ represents different attractions; $t$ represents a certain month; PostEvent $t_{t}$ equals 1 after the event and 0 before the event; TreatedGroup $i$ is assigned the value of 1 if the attraction belongs to the experimental group, and 0 otherwise; $X_{i}$ shows whether the attraction pertains to world heritages; CountryFE, YearFE, and MonthFE represent the fixed effects of country, year, and month, respectively. 
If $\beta_{1}$ was significant in the two models, then the occurrence of events had a significant impact on the number of tourists and tourist experience.

\subsection{Data}

Firstly, in respect to the selection of countries, according to The Travel and Tourism Competitiveness Report 2019 issued by the WEF(World Economic Forum), countries in the experimental group and the control group were selected among the 20 countries whose tourism industries are the most competitive in the world-that is, where tourism occupies an essential position in the national economies of these countries. Secondly, with respect to the selection of events, the countries that have experienced terrorist attacks or earthquakes in the past decade were selected as the experimental group with reference to the Wikipedia Chronology of each country. (To assure the effectiveness of the samples, there should have been no other disaster event in the selected countries in the three months before and after the window period.) At the same time, neighboring or similar countries where no disaster had occurred were selected as the control group (Table 1). Thirdly, in respect to the data resources of the number of tourists and tourist experience, online reviews on TripAdvisor were taken as research objects in this paper. Five attractions with the most online reviews in each control group and experimental group countries were chosen (Table 2). Afterwards, the data from several dimensions, including title, username, comment content, experience date, comment date, user location, star rating, etc., were obtained by means of the "web crawler" program. Among them, the number of tourists who commented on the experience of the month was taken as the number of tourists in that month, while their star rating information was regarded as their experience result. In this way, abundant real and valid tourist data were acquired.

Table 1. List of countries and events.

\begin{tabular}{|c|c|c|c|c|}
\hline $\begin{array}{c}\text { Countries in the } \\
\text { Experimental Group }\end{array}$ & $\begin{array}{l}\text { Countries in the } \\
\text { Control Group }\end{array}$ & Occurrence Date & Type of Event & Casualty \\
\hline \multirow{3}{*}{ France } & \multirow{3}{*}{ Italy } & 2015-01-07 & Terrorist attack & 12 deaths, 11 injuries \\
\hline & & $2015-11-13$ & Terrorist attack & 130 deaths, 352-368 injuries \\
\hline & & 2016-07-14 & Terrorist attack & 86 deaths, 458 injuries \\
\hline \multirow{2}{*}{ Germany } & \multirow{2}{*}{ Spanish } & 2016-12-19 & Terrorist attack & 12 deaths, 56 injuries \\
\hline & & 2018-04-07 & Terrorist attack & 4 deaths, 20 injuries \\
\hline Japan & Singapore & 2011-03-11 & Earthquake & $\begin{array}{c}15,895 \text { deaths, } 2553 \text { disappearances, } \\
6152 \text { injuries }\end{array}$ \\
\hline \multirow{4}{*}{ New Zealand } & \multirow{4}{*}{ Australia } & 2010-09-04 & Earthquake & 1 death, 2 injuries \\
\hline & & 2011-02-22 & Earthquake & 185 deaths \\
\hline & & 2014-01-20 & Earthquake & 2 injuries \\
\hline & & 2016-11-14 & Earthquake & 2 deaths \\
\hline
\end{tabular}

Table 2. Selection of attractions in countries.

\begin{tabular}{|c|c|c|c|}
\hline $\begin{array}{l}\text { Countries in the } \\
\text { Experimental Group }\end{array}$ & Attractions & $\begin{array}{l}\text { Countries in the } \\
\text { Control Group }\end{array}$ & Attractions \\
\hline \multirow{5}{*}{ France } & Eiffel Tower & \multirow{3}{*}{ Italy } & Colosseum \\
\hline & Louvre Museum & & Pantheon \\
\hline & Cathedrale Notre-Dame de Paris & & Duomo di Milano \\
\hline & Musee d'Orsay & & Canal Grande \\
\hline & Arc de Triomphe & \multirow{5}{*}{ Spain } & St. Peter's Basilica \\
\hline \multirow{4}{*}{ Germany } & Brandenburg Gate & & Basilica of the Sagrada Familia \\
\hline & The Holocaust Memorial & & Casa Batllo \\
\hline & Marienplatz & & Plaza de Espana \\
\hline & Miniatur Wunderland & & The Alhambra \\
\hline \multirow{5}{*}{ Japan } & Kolner Dom & \multirow{6}{*}{ Singapore } & Royal Palace of Madrid \\
\hline & Fushimi Inari-taisha Shrine & & Gardens by the Bay \\
\hline & Kinkakuji Temple & & Singapore Zoo \\
\hline & Kiyomizu-dera Temple & & Singapore Flyer \\
\hline & Dotonbori & & Marina Bay Sands Skypark \\
\hline \multirow{6}{*}{ New Zealand } & Universal Studios Japan & & Cloud Forest \\
\hline & Museum of New Zealand & \multirow{5}{*}{ Australia } & Sydney Opera House \\
\hline & Sky Tower & & Sydney Harbour \\
\hline & Wai-O-Tapu Thermal Wonderland & & Sydney Ferries \\
\hline & Hobbiton Movie Set & & Sydney Harbour Bridge \\
\hline & Christchurch Botanic Gardens & & Kings Park and Botanic Gardena \\
\hline
\end{tabular}




\section{Results and Conclusions}

\subsection{Results}

It can be seen from Table 3 that, on the whole, the terrorist attacks in both Germany and France had a significant negative effect on the number of tourists, so H2a was supported. However, the absolute value of the correlation coefficient of Germany was greater than that of France, so H2c was not supported. In the earthquakes, the correlation coefficient of New Zealand was notably negative, but the negative result of Japan was not significant. This may have been because it was a long time since the event occurred in Japan, and the number of reviews on TripAdvisor and the sample size were insufficient. As a result, H1a was partly supported. The absolute value of the correlation coefficient of New Zealand was larger than that of Japan, so H1c was partly supported.

Table 3. Impact of disaster events on the number of tourists.

\begin{tabular}{|c|c|c|c|c|}
\hline & (1) & (2) & (3) & (4) \\
\hline & $\begin{array}{l}\text { Japan vs. } \\
\text { Singapore }\end{array}$ & $\begin{array}{c}\text { New Zealand vs. } \\
\text { Australia }\end{array}$ & $\begin{array}{c}\text { Germany vs. } \\
\text { Spain }\end{array}$ & France vs. Italy \\
\hline Post Event $\times$ & -0.350 & $-0.448 *$ & $-0.312^{+}$ & $-0.213 *$ \\
\hline Treated Group & $(0.256)$ & $(0.212)$ & $(0.167)$ & $(0.106)$ \\
\hline \multirow{2}{*}{ Post Event } & $1.420 * * *$ & $0.423^{* *}$ & 0.097 & 0.159 * \\
\hline & $(0.186)$ & $(0.139)$ & $(0.111)$ & $(0.069)$ \\
\hline \multirow{2}{*}{ Treated Group } & $1.191^{* * *}$ & $-1.854^{* * *}$ & $-0.549 * * *$ & $1.269^{* * *}$ \\
\hline & $(0.190)$ & $(0.158)$ & $(0.124)$ & $(0.075)$ \\
\hline \multirow{2}{*}{ World Heritage } & $0.387^{* *}$ & $0.916^{* * *}$ & $0.347^{* * *}$ & $0.465^{* * *}$ \\
\hline & $(0.140)$ & $(0.171)$ & $(0.088)$ & $(0.053)$ \\
\hline Country FE & $\mathrm{Y}$ & $\mathrm{Y}$ & $\mathrm{Y}$ & $\mathrm{Y}$ \\
\hline Year FE & Y & Y & Y & Y \\
\hline Month FE & $\mathrm{Y}$ & $\mathrm{Y}$ & $\mathrm{Y}$ & $\mathrm{Y}$ \\
\hline \multirow{2}{*}{ Constant } & $3.205^{* * *}$ & $3.542 * * *$ & $8.618^{* * *}$ & $6.668^{* * *}$ \\
\hline & $(0.138)$ & $(0.155)$ & $(0.119)$ & $(0.068)$ \\
\hline $\mathrm{N}$ & 57 & 201 & 120 & 180 \\
\hline $\mathrm{R} 2$ & 0.777 & 0.869 & 0.594 & 0.829 \\
\hline
\end{tabular}

Notes: Standard errors in parentheses. $+p<0.10,{ }^{*} p<0.05,{ }^{* *} p<0.01,{ }^{* * *} p<0.001$.

It can be seen from Table 4 that, on the whole, the terrorist attacks in both Germany and France had a significant negative effect on the tourism experience. Accordingly, H2b was supported. However, the absolute value of the correlation coefficient of Germany was greater than that of France, so $\mathrm{H} 2 \mathrm{~d}$ was not supported. In the earthquakes, the correlation coefficient of New Zealand was significant and negative, but that of Japan was not significant, so H1b was partly supported. The absolute value of the correlation coefficient of New Zealand was larger than that of Japan, so H1d was partly supported.

Based on the results described above, it can be concluded that the two types of disasters had a noteworthy negative impact on the number of tourists and the tourist experience. Specifically, for either the number of tourists or the tourist experience, the absolute value of the correlation coefficient of the interaction terms in Germany was greater than that in France. It can be seen that compared to those in Germany, a higher frequency and intensity of terrorist attacks in France did not correspond to a greater effect on its tourism. This was probably because a terrorist attack would immediately undermine the safety image of Germany, a country whose domestic, social, political, and economic environment has been relatively safe and stable for a long time. At the same time, the absolute value of the correlation coefficient of the interaction term in Japan was smaller than that of New Zealand. It can be concluded that, with regard to earthquakes, the influence of frequency is greater than that of scale and intensity - that is, if earthquakes occur frequently in a country, their impact on its tourism will be 
more considerable. In contrast, even if a large-scale earthquake transiently threatens a country, the tourism in this country can gradually thrive again as long as no other such events occur.

Table 4. Impact of disaster events on the tourist experience.

\begin{tabular}{ccccc}
\hline & $\mathbf{( 1 )}$ & $\mathbf{( 2 )}$ & $\mathbf{( 3 )}$ & $\mathbf{( 4 )}$ \\
& $\begin{array}{c}\text { Japan vs. } \\
\text { Singapore }\end{array}$ & $\begin{array}{c}\text { New Zealand vs. } \\
\text { Australia }\end{array}$ & $\begin{array}{c}\text { Germany vs. } \\
\text { Spain }\end{array}$ & France vs. Italy \\
\hline Post Event $\times$ & 0.044 & $-0.127^{* * *}$ & $-0.214^{* * *}$ & $-0.207^{* * *}$ \\
Treated Group & $(0.042)$ & $(0.013)$ & $(0.003)$ & $(0.002)$ \\
Post Event & $-0.074^{+}$ & $0.034^{* * *}$ & $0.303^{* * *}$ & $0.032^{* * *}$ \\
& $(0.044)$ & $(0.009)$ & $(0.003)$ & $(0.002)$ \\
Treated Group & 0.058 & $-0.338^{* * *}$ & $-0.545^{* * *}$ & $1.305^{* * *}$ \\
World Heritage & $(0.038)$ & $(0.008)$ & $(0.002)$ & $(0.001)$ \\
Country FE & -0.024 & $-0.060^{* * *}$ & $0.480^{* * *}$ & $0.484^{* * *}$ \\
Year FE & $(0.020)$ & $(0.003)$ & $(0.001)$ & $(0.001)$ \\
Month FE & $\mathrm{Y}$ & $\mathrm{Y}$ & $\mathrm{Y}$ & $\mathrm{Y}$ \\
Constant & $\mathrm{Y}$ & $\mathrm{Y}$ & $\mathrm{Y}$ & $\mathrm{Y}$ \\
& $\mathrm{Y}$ & $\mathrm{Y}$ & $8.431^{* * *}$ & $\mathbf{Y}$ \\
$\mathrm{N}$ & $4.515^{* * *}$ & $4.632^{* * *}$ & $(0.002)$ & $(0.003)$ \\
\hline r2 & $(0.042)$ & $(0.016)$ & $422,705.000$ & $748,180.000$ \\
\hline
\end{tabular}

Notes: Standard errors in parentheses. $+p<0.10,{ }^{* * *} p<0.001$. The values in black italics represent the normalization coefficient.

In addition, by comparing the consequences of earthquakes and terrorist attacks, it can be seen that earthquakes had a greater effect on the number of tourists than terrorist attacks: that is, after the earthquakes, the number of tourists decreased more obviously. This may be because secondary disasters, such as tsunami, landslides, floods, and plagues, often occur subsequently after the earthquakes, exerting a continuous influence on tourism. At the same time, earthquakes had a smaller effect on the tourist experience than terrorist attacks, which meant that tourists visiting the earthquake-stricken area would have a slightly better perception than those visiting the area suffering from terrorist attacks. This may be because the congestion in popular scenic spots was relieved with the sharp decline in the number of tourists after the disaster, and the tourist experience will be improved accordingly.

\subsection{Conclusions}

Various disasters, including natural disasters, terrorist attacks, technical disasters, and infectious diseases, can affect the survival and normal operation of the tourism industry. It is illustrated in this study that natural and man-made disasters have a negative impact on both the number of tourists and the tourist experience. Therefore, it is necessary to strengthen the prevention of these disasters to diminish the probability of disaster occurrence. Obviously, in terms of saving people's lives and property, pre-disaster management is always superior to, and more effective than, post-disaster rescue [41]. Only by making effective preparations for disaster prevention can the impact of future disasters on human life, health, and property be reduced [56]. Secondly, it is also found in this study that a higher frequency and intensity of terrorist attacks may not correspond to a greater effect on its tourism, and terrorist attacks exert a more influential impact on the safety image of tourist destinations. Therefore, after the disaster, it is suggested to pay more attention to the restoration of the safety image, try to change tourists' perception of insecurity, and eliminate the instability of the tourism industry after the turmoil. Thirdly, it is clarified in this study that the impact of the frequency of earthquakes on tourism is greater than the effect of its scale and intensity. Therefore, for earthquake-prone areas, the earthquake resistance level and prevention of building and infrastructure damage should be enhanced, and relevant safety education for tourists and local residents should be reinforced—e.g., by providing 
enough safety tips in multiple languages (or, at least, English). By adopting the above measures, the damage can be minimized once an earthquake occurs. Finally, it is found that earthquakes have a greater effect on the number of tourists than terrorist attacks. The same type of disasters occurring in different countries and different types of disasters occurring in the same country both have different degrees of impact on tourists. This result further verifies the conclusion of Fishbein's multi-attribute attitude model: self-awareness forms emotions that further affect the consumer's decision-making, and choice of a tourist destination is related to the long-term accumulated image of the tourist destination in their mind. In the key link of decision-making, the image will play a role quietly, finally influence the overall tourist flow of the tourist destination, and then affect the development of the local tourism economy. Therefore, after an earthquake, we must accelerate the recovery and reconstruction and restore the safety image of the tourist destination in the international tourism market as soon as possible. Only in this way can we effectively establish the confidence of tourists in consumption decision-making and ultimately promote the healthy development of the tourist economy in the tourist destination.

\section{Limitations}

Firstly, people's perception of tourism risk and their decision-making process are affected not only by security factors, but also by their social demographic and economic characteristics, such as age, gender, education, religion, tourism motivation, personal experience, and income. Secondly, the impact of disaster events on tourism at a destination depends not only on the nature, scale, and frequency of the events, but also on the tourism resilience of the destination. Thirdly, this study chooses two similar or adjacent countries—one as the control group and the other as the experimental group — but the influences of possible differences (culture, society, etc.) between countries on tourists' decision-making are not considered.

Author Contributions: Conceptualization, J.Z. and X.T.; Methodology, X.T. and J.Z.; Software, X.T. and J.Z.; Data Curation, X.T. and J.Z.; Writing-Original Draft Preparation, H.M., J.Z., and X.T.; Writing-Review and Editing, H.M., Y.-h.C., and Q.G.; Supervision, H.M., Y.-h.C., and Q.G. All authors have read and agreed to the published version of the manuscript.

Funding: This research was supported by “the National Social Science Foundation of China (Grant No. 15BGL121)", "Jiangsu's high-end training program for the specialty leading person in higher vocational colleges (Grant No. 2019GRFX087)" and "the Qinglan Project of Jiangsu Province", "the Ministry of Education of Humanities and Social Science Project of China (Grant No. 18YJA630061)", and "the Jiangsu Social Science Foundation Project (Grant No. 18EYB009)".

Acknowledgments: We gratefully acknowledge the funding support from "the National Social Science Foundation of China (Grant No. 15BGL121)". The authors wish to thank the anonymous reviewers and the editor of the special volume for their excellent and insightful comments.

Conflicts of Interest: The authors declare no conflict of interest.

\section{References}

1. Wu, J. Research on the approach to targeted poverty alleviation by rural tourism. Rural Econ. 2017, 3, 105-109.

2. Shan, C. New concepts leading the new direction of tourism development. City 2018, 4, 55-59.

3. Zhang, L. Review on the definitions and concept of tourism currently popular in the world-Recognition of the nature of tourism. Tour Trib. 2008, 23, 86-91.

4. $\mathrm{Wu}, \mathrm{X}$; $\mathrm{Li}, \mathrm{T}$. An Analysis of the connotation of Tourist Destination Competitiveness and Its Conceptual Model: The Perspectives of Language, Logic and Epistemology. Tour. Sci. 2013, 3, 18-25+71.

5. Guo, S.; Cao, N. An explanation of the competitiveness of tourist destinations. Nankai Bus. Rev. 2004, 7 , 95-99.

6. Sk, K.; Chc, H. Dyadic consensus on family vacation destination selection. Tour. Manag. 2005, 26, 571-582.

7. Nanda, D.; Hu, C.; Bai, B. Exploring Family Roles in Purchasing Decisions during Vacation Planning. J. Travel Tour. Mark. 2007, 20, 107-125. [CrossRef]

8. Hung, L. Married couples' decision-making about household natural hazard preparedness: A case study of hurricane hazards in Sarasota County, Florida. Nat. Hazards 2017, 87, 1057-1081. [CrossRef] 
9. Kaplan, L.; Szybillo, G.; Jacoby, J. Components of perceived risk in product purchase: A cross-validation. J. Appl. Psychol. 1974, 59, 287-291. [CrossRef]

10. Khazai, B.; Mahdavian, F.; Platt, S. Tourism Recovery Scorecard (TOURS)—Benchmarking and monitoring progress on disaster recovery in tourism destinations. Int. J. Disaster Risk Reduct. 2018, 27, 75-84. [CrossRef]

11. Mair, J.; Ritchie, B.W.; Walters, G. Towards a research agenda for post-disaster and post-crisis recovery strategies for tourist destinations: A narrative review. Curr. Issues Tour. 2016, 19, 1-26. [CrossRef]

12. Nian, S.; Zhang, J.; Zhang, H.; Zhang, J.; Li, D.; Wu, K.; Chen, X.; Yang, L. Two Sides of a Coin: A Crisis Response Perspective on Tourist Community Participation in a Post-Disaster Environment. Int. J. Environ. Res. Public Health 2019, 16, 2073. [CrossRef] [PubMed]

13. Huang, J.; Min, J. Earthquake devastation and recovery in tourism: The Taiwan case. Tour. Manag. 2002, 23, 145-154. [CrossRef]

14. Sharpley, R. The tsunami and tourism: A comment. Curr. Issues Tour. 2005, 8, 344-349. [CrossRef]

15. Park, K.; Reisinger, Y. Differences in the Perceived Influence of Natural Disasters and Travel Risk on International Travel. Tour. Geogr. 2010, 12, 1-24. [CrossRef]

16. Hall, C. Crisis events in tourism: Subjects of crisis in tourism. Curr. Issues Tour. 2010, 13, 401-417. [CrossRef]

17. Morakabati, Y.; Beavis, J. Do Terrorist Attacks Leave an Identifiable 'Fingerprint' on International Tourist Arrival Data? Int. J. Tour. Res. 2017, 19, 179-190. [CrossRef]

18. Kim, J.S.; Park, S.H. A Study of the Negotiation Factors for Korean Tourists Visiting Japan since the Fukushaima Nuclear Accident Using Q-Methodology. J. Travel Tour. Mark. 2016, 33, 770-782. [CrossRef]

19. Arana, J.E.; Leon, C.J. The impact of terrorism on tourism demand. Ann. Tour. Res. 2008, 35, $299-315$. [CrossRef]

20. Chan, C.; Nozu, K.; Cheung, T. Tourism and natural disaster management process: Perception of tourism stakeholders in the case of Kumamoto earthquake in Japan. Curr. Issues Tour. 2019, 9, 1-22. [CrossRef]

21. Beirman, D. BEST Education Network Think Tank V Keynote Address: "Marketing tourism destinations from crisis to recovery". Tour. Rev. Int. 2006, 10, 7-16. [CrossRef]

22. Poku, G.; Boakye, K.A.A. Insights into the safety and security expressions of visitors to the Kakum National Park: Implications for management. Tour. Manag. Perspect. 2019, 32, 100562. [CrossRef]

23. Murphy, P.E.; Bayley, R. Tourism and disaster planning. Geogr. Rev. 1989, 79, 36-46. [CrossRef]

24. Carter, W.N. Disaster Management: A Disaster Manager's Handbook; Asian Development Bank: Manila, Philippines, 1991.

25. Briere, J.; Elliott, D. Prevalence, characteristics, and long-term sequelae of natural disaster exposure in the general population. J. Trauma. Stress 2000, 13, 661-679. [CrossRef] [PubMed]

26. Perrow, C. The Next Catastrophe: Reducing Our Vulnerabilities to Natural, Industrial, and Terrorist Disasters; Princeton University Press: Princeton, NJ, USA, 2011.

27. Becken, S.; Hughey, K.F.D. Linking tourism into emergency management structures to enhance disaster risk reduction. Tour. Manag. 2013, 36, 77-85. [CrossRef]

28. Bauman, M.; Yuan, J.; Williams, H. Developing a measure for assessing tourists' empathy towards natural disasters in the context of wine tourism and the 2017 California wildfires. Curr. Issues Tour. 2019, 10, 1-16. [CrossRef]

29. Corbet, S.; O'Connell, J.F.; Efthymiou, M.; Guiomard, C.; Lucey, B. The impact of terrorism on European tourism. Ann. Tour. Res. 2019, 75, 1-17. [CrossRef]

30. Wang, C.; Wu, J.; He, X.; Ye, M.; Liu, W.; Tang, R. Emerging Trends and New Developments in Disaster Research after the 2008 Wenchuan Earthquake. Int. J. Environ. Res. Public Health 2019, 16, 29. [CrossRef]

31. Gunn, C.A. Vacations Cape: Designing Tourist Regions; Van Nostrand Reinhold: New York, NY, USA, 1988.

32. Fletcher, J.; Morakabati, Y. Tourism Activity, Terrorism and Political Instability within the Commonwealth: The cases of Fiji and Kenya. Int. J. Tour. Res. 2008, 10, 537-556. [CrossRef]

33. Seabra, C.; Dolnicar, S.; Abrantes, J. Elisabeth Kastenholz. Heterogeneity in risk and safety perceptions of international tourists. Tour. Manag. 2013, 36, 502-510. [CrossRef]

34. Fareed, Z.; Meo, M.S.; Zulfiqar, B.; Shahzad, F.; Wang, N. Nexus of tourism, terrorism, and economic growth in Thailand: New evidence from asymmetric ARDL cointegration approach. Asia Pac. J. Tour. Res. 2018, 23, 1129-1141. [CrossRef]

35. Mendiratta, A. Come Closer: How Tourism is Shaping the Future of Nations, New eds.; Sterling Publishers Private Ltd.: New York, NY, USA, 2011. 
36. Neumayer, E. The Impact of Political Violence on Tourism. J. Confl. Resolut. 2004, 48, 259-281. [CrossRef]

37. Reisinger, Y.; Mavondo, F. Travel Anxiety and Intentions to Travel Internationally: Implications of Travel Risk Perception. J. Travel Res. 2005, 43, 212-225. [CrossRef]

38. Rodda, J. The natural of hazards. In Natural Disaster Management; Ingleton, J., Ed.; Tudor Rose Holdings Ltd.: Leicester, UK, 1999.

39. Weisaeth, L.; Knudsen, O.; Tonnessen, A. Technological disasters, crisis management and leadership stress. J. Hazard. Mater. 2002, 9, 33-45. [CrossRef]

40. Sönmez, S.F.; Graefe, A.R. Influence of terrorism risk on foreign tourism decisions. Ann. Tour. Res. 1998, 25, 112-144. [CrossRef]

41. Kang, P.; Lv, Y.; Deng, Q.; Liu, Y.; Zhang, Y.; Liu, X.; Zhang, L. Investigating Lushan Earthquake Victims' Individual Behavior Response and Rescue Organization. Int. J. Environ. Res. Public Health 2017, 14, 1556. [CrossRef]

42. Henderson, J.C.; $\mathrm{Ng}$, A. Responding to crisis: Severe acute respiratory syndrome (SARS) and hotels in Singapore. Int. J. Tour. Res. 2004, 6, 411-419. [CrossRef]

43. Zhao, J.; Ding, F.; Wang, Z.; Ren, J.; Zhao, J.; Wang, Y.; Tang, X.; Wang, Y.; Yao, J.; Li, Q. A Rapid Public Health Needs Assessment Framework for after Major Earthquakes Using High-Resolution Satellite Imagery. Int. J. Environ. Res. Public Health 2018, 15, 1111. [CrossRef]

44. Huan, T.; Beaman, J.; Shelby, L. No-escape natural disaster: Mitigating impacts on tourism. Ann. Tour. Res. 2004, 31, 255-273. [CrossRef]

45. Rittichainuwat, B.N. Tourists' and tourism suppliers' perceptions toward crisis management on tsunami. Tour. Manag. 2013, 34, 112-121. [CrossRef]

46. Hasegawa, M.; Murakami, M.; Takebayashi, Y.; Suzuki, S.; Ohto, H. Social Capital Enhanced Disaster Preparedness and Health Consultations after the 2011 Great East Japan Earthquake and Nuclear Power Station Accident. Int. J. Environ. Res. Public Health 2018, 15, 516. [CrossRef] [PubMed]

47. Available online: http://m.sohu.com/a/217618922_670998 (accessed on 19 January 2018).

48. Causevic, S.; Lynch, P. Political (in) stability and its influence on tourism development. Tour. Manag. 2013, 34, 145-157. [CrossRef]

49. Wolff, K.; Larsen, S. Can terrorism make us feel safer? Risk perceptions and worries before and after the July 22nd attacks. Ann. Tour. Res. 2014, 44, 200-209. [CrossRef]

50. Liu, A.; Pratt, S. Tourism's vulnerability and resilience to terrorism. Tour. Manag. 2017, 60, $404-417$. [CrossRef]

51. Lanouar, C.; Goaied, M. Tourism, terrorism and political violence in Tunisia: Evidence from Markov-switching models. Tour. Manag. 2019, 70, 404-418. [CrossRef]

52. Lepp, A.; Gibson, H. Tourist roles, perceived risk and international tourism. Ann. Tour. Res. 2003, 30, 606-624. [CrossRef]

53. Bowen, C.; Fidgeon, P.; Page, S. Maritime tourism and terrorism: Customer perceptions of the potential terrorist threat to cruise shipping. Curr. Issues Tour. 2014, 17, 610-639. [CrossRef]

54. Payne, J.; Gil-Alana, L. Data measurement and the change in persistence of tourist arrivals to the United States in the aftermath of the September 11th terrorist attacks. Tour. Econ. 2018, 24, 41-50. [CrossRef]

55. Hadi, D.; Katircioglu, S.; Adaoglu, C. The vulnerability of tourism firms' stocks to the terrorist incidents. Curr. Issues Tour. 2019, 3, 1-14. [CrossRef]

56. Tang, J.; Feng, J. Residents' Disaster Preparedness after the Meinong Taiwan Earthquake: A Test of Protection Motivation Theory. Int. J. Environ. Res. Public Health 2018, 15, 1434. [CrossRef]

(C) 2020 by the authors. Licensee MDPI, Basel, Switzerland. This article is an open access article distributed under the terms and conditions of the Creative Commons Attribution (CC BY) license (http://creativecommons.org/licenses/by/4.0/). 